\title{
Adenocarcinoma arising in Barrett's oesophagus: evidence for the participation of $\mathrm{p} 53$ dysfunction in the dysplasia/carcinoma sequence
}

\author{
R H Hardwick, N A Shepherd, M Moorghen, P V Newcomb, D Alderson
}

\begin{abstract}
Adenocarcinoma arising in Barrett's oesophagus is often preceded by mucosal dysplasia, but little is currently known about the aetiology or natural history of this dysplasia/ carcinoma sequence. To investigate the participation of the tumour suppressor gene p53 in this sequence, an immunohistochemical analysis of $\mathrm{p} 53$ protein overexpression, which is known to closely correlate with point mutation of the p53 gene, was conducted in 30 patients with Barrett's adenocarcinoma. Adjacent Barrett's mucosa was dysplastic in $\mathbf{2 1}$ (70\%) patients. Sixteen (53\%) tumours overexpressed p53, 10 of which had adjacent dysplastic Barrett's mucosa. In all 10 patients, this dysplastic mucosa also overexpressed p53, predominantly in areas of high grade compared with low grade dysplasia. In contrast, none of the dysplastic mucosa adjacent to 11 tumours lacking p53 overexpression showed detectable values of $\mathrm{p} 53$. These results suggest that $\mathrm{p} 53$ dysfunction may participate in the progression from dysplasia to carcinoma in some patients with Barrett's oesophagus. (Gut 1994; 35: 764-768)
\end{abstract}

In $10-15 \%$ of patients with chronic gastrooesophageal reflux disease areas of the distal squamous oesophageal epithelium are replaced by metaplastic columnar mucosa, ${ }^{1-4}$ a condition known eponymously as Barrett's oesophagus. ${ }^{56}$ This unique mucosa consists of a mosaic of distinct cell types, which represent the variable differentiation of an as yet unidentified multipotent stem cell. . $^{7-10}$

Patients with Barrett's oesophagus have an increased risk of developing oesophageal adenocarcinoma. ${ }^{10-13}$ Carcinoma is predominantly associated with specialised intestinal type mucosa and preceded by dysplasia. ${ }^{1415}$ High grade dysplasia is often associated with oesophageal adenocarcinoma and its discovery should prompt an extensive search for microinvasive malignancy. ${ }^{16-20}$ Low or indefinite grade dysplasia is of less certain prognostic significance. It is difficult to characterise reliably ${ }^{21}$ and has an uncertain natural history, although flow cytometry can detect clonal genomic instability in dysplastic Barrett's mucosa, which may be useful in predicting the risk of progression to high grade dysplasia or cancer. ${ }^{22}$

Mutations and deletions of the tumour suppressor gene p53 have stimulated considerable interest because of their high frequency in human cancer. ${ }^{23-25}$ Current evidence suggests that p53 mediates a G1 cell cycle arrest after genomic damage, ${ }^{26}$ and that loss of $\mathrm{p} 53$ function may permit immortalisation of this damage by its incorporation into the next cycle of synthesis and mitosis. ${ }^{27}$ Many mutant forms of $\mathrm{p} 53$ protein are 'overexpressed' secondary to a poorly understood increase in post-translational stability, which makes them detectable immunohistochemically. 2829

$17 p$ allelic deletions (the site of the $p 53$ gene) are common in colorectal adenocarcinomas, especially in conjunction with p 53 mutation in the remaining allele. ${ }^{30} 17 \mathrm{p}$ deletions are also a common finding in Barrett's adenocarcinomas ${ }^{31}$ and Barrett's mucosa showing high grade dysplasia. ${ }^{32}$ In addition, p53 overexpression has been detected in Barrett's adenocarcinoma and in some patients with dysplastic Barrett's mucosa. ${ }^{33}$ In contrast with these immunohistochemical findings, DNA sequence analysis has found p53 missense mutations in the columnar mucosa adjacent to some Barrett's adenocarcinomas, but not in the tumour themselves. ${ }^{3+}$

To investigate this apparently conflicting evidence, an immunohistochemical investigation was performed, comparing p53 expression in Barrett's adenocarcinomas and the surrounding dysplastic columnar mucosa from which these tumours are presumed to have arisen.

\section{Materials and Methods}

\section{TISSUES}

Thirty patients with oesophageal adenocarcinoma arising in Barrett's oesophagus (mean age 68 years, M:F 22:8) were identified from histopathology computer records of the Bristol Royal Infirmary, Gloucestershire Royal Hospital, and Frenchay Hospital. These were defined as adenocarcinomas arising in the tubular oesophagus associated with specialised intestinal type Barrett's mucosa. ${ }^{35}$ All tissues had been routinely fixed in buffered formal saline. Twenty patients with non-dysplastic Barrett's oesophagus (mean age 62 years, M:F 14:6) receiving endoscopic surveillance acted as a control group. Haematoxylin and eosin stained sections were graded for dysplasia ${ }^{36} 37$ by two consultant pathologists independently (NAS and $M M$ ), with consensus scoring for those sections where there was initial disagreement.

\section{Methods}

Tissue sections of $5 \mu \mathrm{m}$ were cut from each block and floated onto poly-1-lysine (Sigma) coated slides and left to dry overnight before 
being dewaxed in histoclear (Cell Path plc) and rehydrated in graded alcohols. The polyclonal antibody CM-1 (Novacastra) was used to stain for p53 protein as previously described. ${ }^{38}$ The StrAviGen (Biogenex) detection system was used according to the manufacturer's instructions and 3,3 diaminobenzidine with $0 \cdot 3 \%$ nickel sulphate were used as chromogens. A light haematoxylin counterstain was applied to permit identification of morphology.

Two sections of breast tumour with a characterised p53 gene mutation causing p53 protein overexpression were stained with each batch of slides to act as positive and negative controls, the latter being incubated without primary antibody.

Staining was assessed independently by two of the authors (RHH and PVN) in the following manner. At low power, the area of interest was identified and 10 random fields of 50 cells were examined under high power. The numbers of unequivocally positive staining nuclei were counted and expressed as a percentage of the total. Four patterns of staining were seen: $I=$ no staining, II $=<1 \%$, III $=1-9 \%$, and $\mathrm{IV}=10$ $100 \%$. Patterns III and IV were considered positive.

\section{Results}

p53 EXPRESSION IN BARRETT'S ADENOCARCINOMA Sixteen (53\%) of the 30 Barrett's adenocarcinomas showed overexpression of p53 (Table I). Staining was exclusively nuclear, specific for neoplasia, and commonly heterogeneous (Fig 1). In two tumours, only occasional isolated staining was seen, amounting to less than $1 \%$ and these were considered negative.

\section{p53 EXPRESSION IN COLUMNAR MUCOSA ADJACENT} TO TUMOURS

The columnar mucosa adjacent to 18 of the tumours showed high grade dysplasia (HGD) with or without low grade dysplasia (LGD). LGD alone was found in three cases, bringing the total number of tumours with adjacent dysplasia to $21(70 \%)$. Of the 16 carcinomas overexpressing $\mathrm{p} 53,10$ had high grade dysplastic Barrett's mucosa adjacent to them. In all 10 cases this dysplastic mucosa overexpressed p 53 (Table II). The pattern of overexpression in dysplasia was predominantly type III (Fig 2), although two cases showed more extensive pattern IV staining (Fig 3). Of the three cases with LGD alone, one was p53 positive. Of the 14 carcinomas not overexpressing p53 11 had areas of adjacent dysplasia, none of which showed overexpression (Table II). None of the non-dysplastic columnar

TABLE II Patterns of p53 overexpression in dysplastic columnar mucosa adjacent to Barrett's adenocarcinoma $(n=21)$

\begin{tabular}{llllll}
\hline Tumour status & Adjacent dysplasia & Pattern I & Pattern II & Pattern III & Pattern IV \\
\hline p53 positive & HGD & 0 & 0 & 7 & 2 \\
p53 positive & LGD & 0 & 0 & 1 & 0 \\
p53 negative & HGD & 8 & 1 & 0 & 0 \\
p53 negative & LGD & 1 & 1 & 0 & 0
\end{tabular}

HGD = high grade dysplasia, LGD= low grade dysplasia. mucosa associated with any of the tumours overexpressed $\mathrm{p} 53$.

\section{p53 EXPRESSION IN CONTROL GROUP}

No $\mathrm{p} 53$ overexpression was detected in any of the columnar biopsy specimens from 20 patients with non-dysplastic Barrett's oesophagus.

\section{p53 EXPRESSION IN DYSPLASTIC COLUMNAR} MUCOSA BEFORE DISCOVERY OF CARCINOMA Three patients (numbers 1, 2, and 30) had endoscopic oesophageal biopsy specimens taken before the detection of invasive carcinoma, 6, 11, and 12 months respectively. All three patients had $\mathrm{p} 53$ positive HGD and in addition, patient 1 and 30 had small areas of LGD that also showed p53 positivity. The oesophageal adenocarcinomas that subsequently developed in each patient also overexpressed $\mathrm{p} 53$.

Patient number 30 was a 72 year old man with a $6 \mathrm{~cm}$ segment of columnar lined oesophagus with a small Barrett's ulcer. Multiple biopsies before treatment showed LGD and HGD in specialised intestinal type mucosa. He was treated with omeprazole $20 \mathrm{mg}$ daily with surveillance endoscopy at three monthly intervals. The dysplasia at the time of initial diagnosis did not overexpress p53 and despite good symptom relief and significant regression of the columnar lined segment, biopsy specimens continued to show LGD and HGD. Between 12 to 18 months after diagnosis, weak pattern III p53 expression was noted in LGD and more intense pattern III staining in HGD. By 24 months p53 positive HGD and areas of early focal stromal invasion were seen in biopsy specimens and he had surgery. The resection specimen confirmed the presence of $\mathrm{p} 53$ positive multifocal microinvasive TIN0 adenocarcinoma.

\section{Discussion}

This study has shown a high prevalence of p53 overexpression in Barrett's adenocarcinoma and in the adjacent dysplastic columnar mucosa from which these tumours are thought to arise. There is a striking positive correlation between p53 overexpression in a carcinoma and the adjacent dysplastic Barrett's mucosa. When present, p53 overexpression in dysplastic mucosa is found mainly in high grade dysplasia with a type III staining pattern. p53 overexpression in carcinomas tended to be more extensive and this is similar to the $\mathrm{p} 53$ expression seen in dysplastic colorectal polyps and adenocarcinomas. ${ }^{39-41}$

There is substantial evidence that p53 overexpression results in most cases, from missense mutation of the p53 gene. ${ }^{42-47}$ Wild type p53 protein is rapidly degraded and not normally detectable immunohistochemically, ${ }^{48}$ whereas mutant forms of p53 are detectable because of their extended half lives. ${ }^{434}$ Doubts, however, concerning the specificity of p53 overexpression have been expressed ${ }^{50}$ as wild type p 53 can be detected in response to DNA damaging agents $^{2651}$ and in some cells during periods of rapid proliferation. ${ }^{52}$ Ultra violet irradiation of normal human skin induces a temporary over- 


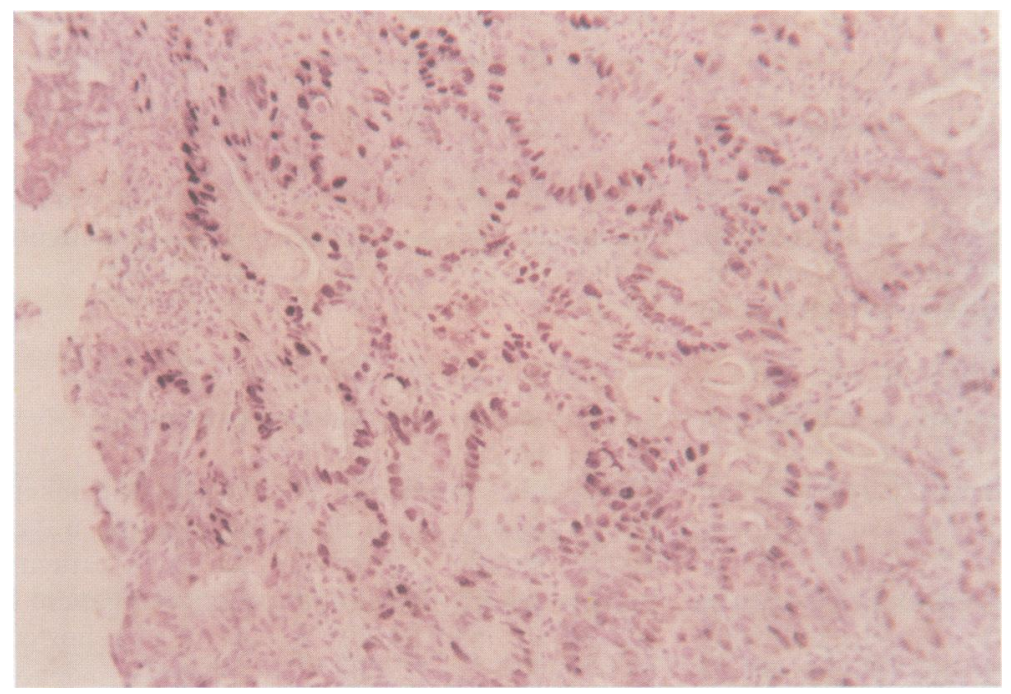

Figure 1: Pattern IV p53 overexpression in a Barrett's adenocarcinoma. Most neoplastic cell nuclei stain with the polyclonal antibody $C M-1$, but with varying intensity (original magnification $\times 200$ ).

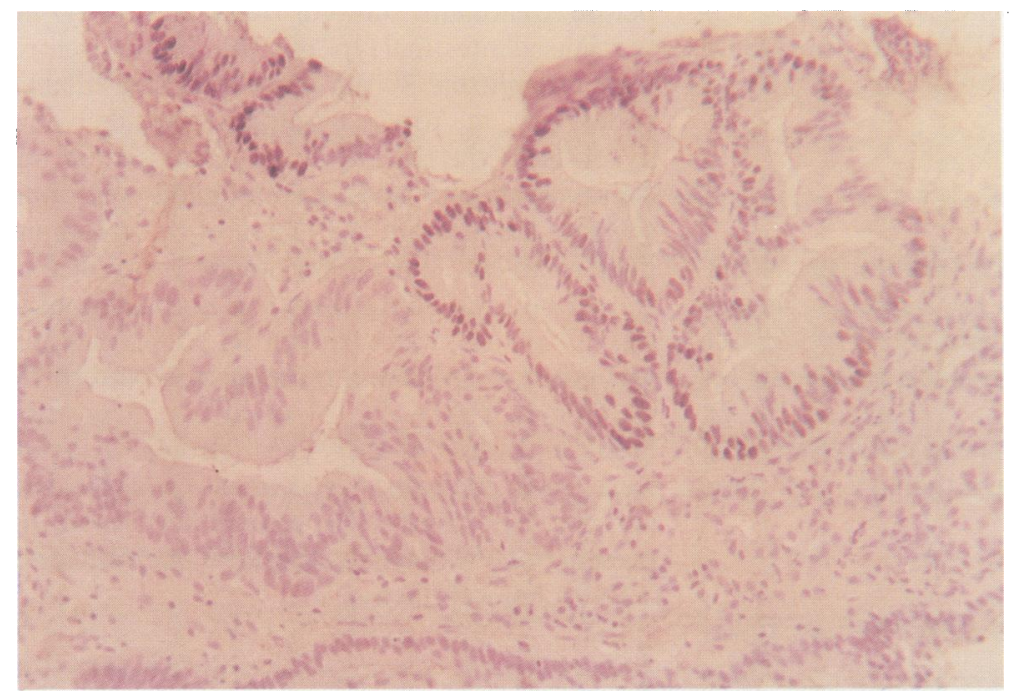

Figure 2: Pattern III p53 overexpression in Barrett's mucosa showing high grade dysplasia. Three glands with variable staining are seen adjacent to a gland with no staining. Overall, $8 \%$ of dysplastic nuclei in this biopsy specimen stained positive (original magnification $\times 200$ ).

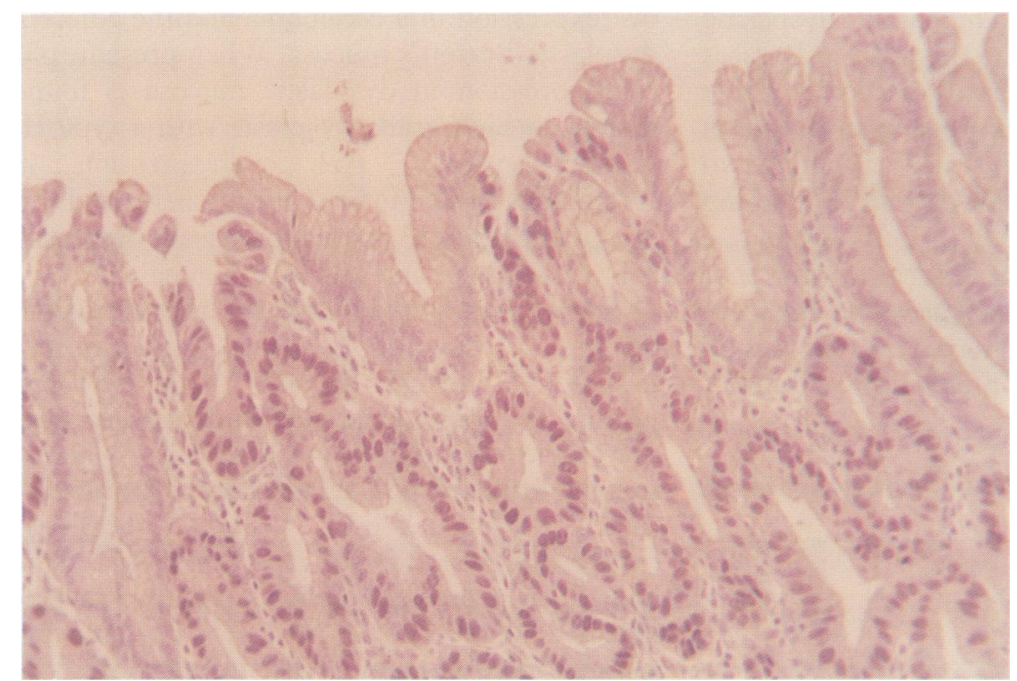

Figure 3: p53 Overexpression (pattern IV) in high grade dysplasia in Barrett's mucosa (original magnification $\times 200)$. expression of wild type $\mathrm{p} 53$ and proliferating cell nuclear antigen (PCNA). ${ }^{53}$ This probably results from the physiological stabilisation of $\mathrm{p} 53$ as it participates in a $\mathrm{Gl}$ cell cycle arrest in response to DNA damage, ${ }^{54}$ and PCNA is required for DNA excision repair. ${ }^{55}$

It is not clear if there is a cut off point for $\mathrm{p} 53$ overexpression below which the association between immunohistochemical detection and gene mutation is lost ( $\mathrm{D}$ Lane personal communication). Widespread overexpression (pattern IV staining) does correlate well with gene mutation, ${ }^{13}+5$ but without analysing the coding regions of the $\mathrm{p} 53$ gene, interpretation of pattern III staining must be more guarded. We can postulate, however, that the strong association between pattern III p53 positivity in dysplastic Barrett's mucosa and pattern IV positivity in Barrett's adenocarcinoma makes it highly probable that the lesser values of $\mathrm{p} 53$ expression do indeed represent evidence of $\mathrm{p} 53$ mutation. If the staining seen in dysplasia resulted from some 'stress' phenomenon we would expect to see staining in dysplasia associated with $\mathrm{p} 53$ positive and negative tumours, but this is not the case. p53 positive dysplasia is only associated with p53 positive carcinoma.

Casson et $\mathrm{ll}^{34}$ investigated exons 5-8 of the p53 gene in neoplastic Barrett's oesophagus using the polymerase chain reaction and single strand conformational polymorphism. They found clonal exon 5 missense mutations in four areas of 'minimally' dysplastic columnar mucosa adjacent to seven Barrett's adenocarcinomas, but unexpectedly, no mutations in the carcinomas. They concluded that any part p53 mutations might have in the formation of these tumours was indirect. Ramel et al ${ }^{33}$ examined 15 Barrett's adenocarcinomas and 11 patients with HGD but without carcinoma using flow cytometric analysis of $\mathrm{p} 53$ protein, and found overexpression in 53\% and $45 \%$ respectively. This study and our own, suggests that p53 mutation may participate directly in the development of Barrett's adenocarcinoma in about $50 \%$ of cases. Furthermore, Flejou et $a l^{56}$ have shown similar results in a series of 11 patients with Barrett's adenocarcinomas. These findings are important to our understanding of malignant transformation in Barrett's oesophagus as loss of p53 function, through allelic deletion and mutation of the remaining allele, may permit cells with an accumulated number of activated protooncogenes to break away from the normal constraints on cell cycle progression and proliferate unchecked..$^{57}$ In the dysplasia/ carcinoma sequence of Barrett's oesophagus, p53 dysfunction seems to occur at a genotypic stage that coincides with the phenotypic events we currently recognise as high grade dysplasia. Whether p53 mutation occurs late in the progression from low grade to high grade, or early in the transition from high grade dysplasia to invasive carcinoma is currently unclear. These results do not suggest that p53 mutation is essential for malignant transformation in columnar lined oesophagus, rather that it is common. Its prevalence is possibly even higher than we have shown, as the influence of technical factors such 
as fixation delay on the detection of $\mathrm{p} 53$ are uncertain. In addition, loss of both p53 alleles or a nonsense mutation resulting in a truncated p 53 protein will not result in overexpression.

p53 overexpression may prove useful clinically in diagnosing high grade dysplasia in Barrett's oesophagus and possibly help identify a subgroup of patients who are at risk of progressing from dysplasia to invasive malignancy. Barrett's oesophagus offers an unrivalled opportunity to observe the premalignant stages of tumour development in vivo in the same patient. Follow up studies of patients with dysplastic Barrett's oesophagus should show if there is a clinical application for $\mathrm{p} 53$ overexpression and provide valuable insight into the role of this important tumour suppressor gene in the multistep development of human malignancy.

The authors are grateful to MWL Gear, SP Wilkinson, and CP Armstrong for their assistance with this study. RH Hardwick is supported by the Carey Coombs Research Fellowship.

1 Mann NS, Tsai MF, Nair PK. Barrett's esophagus in patients with symptomatic reflux esophagitis. Am f Gastroenterol 1990; 99: 918-22.

2 Winters C, Spurling TJ, Chobanian SJ, Curtis DJ, Esposito $\mathrm{RL}$, Hacker JF, et al. Barrett's esophagus. A prevalent, $\mathrm{RL}$, Hacker JF, et al. Barrett's esophagus. A prevalent, occult complication of gastroin

3 GOSPE. Barrett's esophagus: epidemiological and clinical results of a multicentre survey. Int $\mathcal{f}$ Cancer 1992; 48: 364-8. 4 Cameron AJ, Lomboy CT. Barrett's esophagus: age, prevalence and extent of columnar epithelium. Gastroenterology 1992; 103: 1241-5.

5 Barrett NR. Chronic peptic ulcer of the oesophagus and "oesophagitis". Brf Surg 1950; 38: 175-82.

6 Barrett NR. The lower esopohagus lined by columnar epithelium. Surgery 1957; 41: 881-94.

7 Zwas F, Shields HM, Doos WG, Antonioli DA, Goldman H, Ransil BJ, et al. Scanning electron microscopy of Barrett's epithelium and its correlation with light microscopy and mucin stains. Gastroenterology 1986; 90: 1932-41.

8 Bremner CG, Lynch VP, Ellis FH. Barrett's oesophagus: congenital or acquired? An experimental study of oesophageal genital or acquired? An experimental study of oesophageal

8a Gillen P, Keeling P, Byrne PJ, West AB, Hennessey TPJ. Experimental columnar metaplasia in the canine oesophagus. Br F Surg 1988; 75: 113-5.

9 Feurle GE, Helmstaedter V, Buehring A, Bettendorf U, Eckardt VF. Distinct immunohistochemical findings in columnar epithelium of esophageal inlet patch and Barrett's esophagus. Dig Dis Sci 1990; 35: 86-92.

10 Naef AP, Savary M, Ozzello L. Columnar-lined lower esophagus: an acquired lesion with malignant predisposition. F Thorac Cardiovasc Surg 1975; 70: 826-35.

11 Spechler SJ, Robbins AH, Rubins HB, Vincent ME, Heeren $\mathrm{T}$, Doos WG, et al. Adenocarcinoma and Barrett's oesophagus: an overrated risk? Gastroenterology 1984; 87. 927-33.

12 Hameeteman W, Tytgat GNJ, Houthoff HJ, Van Den Tweel JG. Barrett's oesophagus: development of dysplasia and JG. Barrett's oesophagus: development of dyspla

13 Robertson CS, Mayberry JF, Nicholson DA, James PD, Alkinson $M$. Value of endoscopic surveillance in the detection of neoplastic change in Barrett's oesophagus. BrF Surg 1988; 75: 760-3.

14 Miros M, Kerlin P, Walker N. Only patients with dysplasia progress to adenocarcinoma in Barrett's oesophagus. Gut 1991; 32: 1441-6

15 Tytgat GNJ, Hameeteman W. The neoplastic potential of columnar-lined (Barrett's esophagus. World f Surg 1992; 16: $308-12$.

16 Skinner DB, Walther BC, Riddell RH, Schmidt H, Iascone C, DeMeester TR. Barrett's esophagus: comparison of benign and malignant cases. Ann Surg 1983; 198: 554-66.

17 Reid BJ, Weinstein WM, Levin K. Endoscopic biopsies can detect high grade dysplasia or early adenocarcinoma in detect high grade dysplasia or early adenocarcinoma in
Barrett's esophagus without grossly recognizable neoplastic Barrett's esophagus without grossly reco
lesions. Gastroenterology 1988;94: 81-90.

18 Altorki NK, Sunagawa M, Little AG, Skinner DB. Highgrade dysplasia in the columnar-lined esophagus. Am $\mathcal{F}$ Surg 1991; 161: 97-9.

19 Hamilton SR, Smith RRL. The relationship between columnar epithelial dysplasia and invasive adenocarcinoma arising in Barrett's oesophagus. Am f Clin Pathol

20 Saubler EC, Gouillat C, Samaniego C, Guillaud M, Moulinier B. Adenocarcinoma in columnar-lined Barrett's esophagus: analysis of 13 esophagectomies. Am 7 Surg 1985; 150: 365-9.

21 Reid BJ, Haggit RC, Rubin CE, Roth G, Surawicz CM, Belle $\mathrm{GV}$, et al. Observer variation in the diagnosis of dysplasia in Barrett's esophagus. Hum Pathol 1988; 19: 166-78.

22 Reid BJ, Blount PL, Rubin CE, Levine DS, Haggitt RC, Rabibovitch PS. Flow-cytometric and histological pro- gression to malignancy in Barrett's esophagus: prospective endoscopic surveillance of a cohort. Gastroenterolon 1992; 102: 1212-9.

23 Nigro JM, Baker SJ, Preisinger AC, Jessup JM, Hosletter R, Cleary $\mathrm{K}$, et al. Mutations in the p53 gene occur in diverse human tumour types. Nature 1989; 342: 705-8.

24 Hollstein MC, Smits AM, Galiana C, Yamasaki H, Mandard A, Portensky $\mathrm{C}$, et al. Amplification of epidermal growth factor receptor gene but no evidence of ras mutations in primary esophageal cancers. Cancer Res 1988; 48:5119-23.

25 Bartek J, Iggo R, Gannon J, Lane DP. Genetic and immunochemical analysis of mutant $\mathrm{p} 53$ in human breast cancer cell ines. Oncogene 1990; 5: 893-9.

26 Kastan MB, Onyekwere O, Sidransky D, Vogelstein B, Craig RW. Participation of 553 protein in the cellular response to DNA damage. Cancer Res 1991; 51: 6304-11.

27 Vogelstein B, Kinzler KW. p53 function and dysfunction. Cell 1992; 70: 523-6.

28 Rodrigues NR, Rowan A, Smith MEF, Kerr IB, Bodmer WF, Gannon JV, et al. p53 mutations in colorectal cancer. Proc Natl Acad Sci USA 1990; 87: 7555-9.

29 Gannon JV, Greaves R, Iggo R, Lane DP. Activating mutations in 533 produce a common confirmational effect. A monoclonal antibody specific for the mutant form. EMBO 7 1990; 9: 1595-602.

30 Baker SJ, Fearon ER, Nigro JM, Hamilton SR, Preisinger AC, Jessup $M$, et al. Chromosome 17 deletions and $\mathrm{p} 53$ gene mutations in colorectal carcinomas. Science 1989; 244: 217

31 Blount PL, Ramel S, Raskind WH, Haggitt RC, Sanche\% CA, Dean PJ, et al. $17 \mathrm{p}$ allelic deletions and $\mathrm{p} 53$ protein overexpression in Barrett's adenocarcinoma. Cancer Res 1991; 51: 5482-6.

32 Blount PL, Meltzer SJ, Yin J, Huang Y, Krasna MJ, Reid BJ Clonal ordering of $17 \mathrm{p}$ and $5 \mathrm{q}$ allelic losses in Barret dysplasia and adenocarcinoma. Proc Natl Acad Sci USA 1993; 90: 3221-5.

33 Ramel S, Reid BJ, Sanchez CA, Blount PL, Levine DS, Neshat K, et al. Evaluation of p53 protein expression in Barrett's esophagus by two-parameter flow cytometry. Gastroenterology 1992; 102: 1220-8.

34 Casson AG, Mukhopadhayay T, Cleary KR, Ro JY, Levin B Roth JA. 55 gene mutations in Barrett's epithelium and esophageal cancer. Cancer Res 1991; 51: 4495-9.

35 Spechler SJ, Goyal RK. Barrett's oesophagus. N Engl f Med 1986; 6: 362-71.

36 Riddell RH, Goldman H, Ransohoff DF, Appleman HD, Fenoglio CM, Haggitt RC, et al. Dysplasia in inflammatory bowel disease: standardized classification with provisional clinical applications. Hum Pathol 1983; 14: 931-68.

37 Riddell RH, Dysplasia and regression in Barrett's epithelium. In: Spechler SJ, Goyal RK, eds. Barrett's esophagus. pathophysiology, diagnosis, and management. New York: Elsevier Science, 1985; 143-52.

38 Midgley CA, Fisher CJ, Bartek J, Vojtesek B, Lane D, Barnes DM. Analysis of p53 expression in human tumours: an antibody raised against human $\mathrm{p} 53$ expressed in Escherichia coli: $\mathcal{F}$ Cell $S$ ci $1992 ; 101: 183-9$.

39 Pignatelli M, Stamp GWH, Kafiri G, Lane D, Bodmer WF Overexpression of $\mathrm{p} 53$ nuclear oncoprotein in colorectal adenoma. Int 7 Cancer 1992; 50: 683-8.

40 Purdie CA, O'Grady J, Piris J, Wyllie AH, Bird CC. p53 expression in colorectal tumours. Am $\mathcal{F}$ Pathol 1991; 138: $807-13$.

41 Kaklamanis L, Gatter KC, Mortensen N, Baigrie RJ, Heryet $\mathrm{A}$, Lane DP, et al. $\mathrm{p} 53$ expression in colorectal adenomas. Am F Pathol 1993; 142; 87-93.

42 Finlay CA, Hinds PW, Tan TH, Eliyahu D, Oren M, Levine AJ. Activating mutations for transformation by p53 produces a gene product that forms on hsc 70-p53 complex with an altered half-life. Miol Cell Biol 1988; 8: 531-9.

43 Bartek J, Iggo R, Gannon J, Lane DP. Genetic and immunochemical analysis of mutant $\mathrm{p} 53$ in human breast cancer cell lines. Oncogene 1990; 5: 893-9.

44 Iggo R, Gatter K, Bartek J, Lane DP, Harris AL. Increased expression of mutant forms of p 53 oncogene in primary lung expression of mutant forms of $\mathrm{p} 53$.

45 Bennett WP Hollstein MMC, He A, Zhu SM, Rerau JH, Trump BF, et al. Archival analysis of $\mathrm{p} 53$ genetic and protein alterations in Chinese esophageal cancer. Oncogene 1991; 6: 1779-84

6 Gusterson BA, Anbazhagan R, Warren W, Midgley C, Lane DP, O'Hare M, et al. Expression of p53 in premalignant and malignant squamous epithelium. Oncogene 1991; 6: 1785-9.

47 Maestro R, Dolcetti R, Gasparotto D, Doglioni C, Pelucchi S, Barzan L, et al. High frequency of p53 gene alterations associated with protein overexpression in human squamous cell carcinoma of the larynx. Oncogene 1992; 7: 1159-66.

48 Oren $M$, Maltzman W, Levine AJ. Post translational regulation of the $54 \mathrm{~K}$ cellular tumour antigen in normal and transformed cells. Mol Cell Biol 1981; 1: 101-10.

49 Gannon JV, Greaves R, Iggo R, I ane DP. Activating mutations in $\mathrm{p} 53$ produce a common confirmational effect. A monoin p53 produce a common confirmational effect. A mono9: 1595-602.

50 Wynford-Thomas D. p53 in tumour pathology: can we trust immunochemistry? f Pathol 1992; 166: 329-30

51 Maltzman W, C.yzk L UV irradiation stimulates levels of p53 cellular tumour antigen in nontransformed mouse cells. Mol Cell Biol 1984; 4: 1689-94.

52 Kastan MB, Stone KD, Civin CI. Nuclear oncoprotein expression as a function of lineage, differentiation stage, and proliferative status of normal human hematopoietic cells. Blood 1989; 74: 1517-24.

53 Hall PA, McKee PH, Menage HD, Dover R, Lane DP. High 

levels of p53 protein in UV irradiated human skin. Oncogene
1992; 8: 203-7.

54 Kuerbitz SJ, Plunkett BS, Walsh WV, Kastan NB. Wild type p53 is a cell cycle checkpoint determinant following irradiation. Proc Natl Acad Sci USA 1992; 89: 7491-5.

55 Shivji MKK, Kenny MK, Wood RD. Proliferating cell nuclear antigen is required for DNA excision repair. Cell 1992; 69: 367-74

56 Flejou J-F, Potet F, Le Pelletier F, Fekete F, Henin D.
Overexpression of p53 protein in Barrett's syndrome with malignant transformation. $\mathcal{F}$ Clin Pathol 1993; 46: 330-3. 57 Vogelstein B, Fearon ER, Hamilton SR, Kern SF, Preisinge AC, Leppert M, et al. Genetic alterations during colorectal tumour development. $N$ Engl F Med 1988; 319: 525-32.

58 Baker SJ, Preisinger AC, Jessup JM, Paraskeva C, Markowitz $\mathrm{S}$, Willson JKV, et al. p 53 gene mutations occur in combination with allelic deletions as late events in colorectal tumorigenesis. Cancer Res 1990; 50: 7717-22. 